\title{
Quantifying the Value of the Academic Library
}

\author{
Rebecca A. Croxton and Anne Cooper Moore \\ University of North Carolina at Charlotte, USA
}

This project is made possible by the Association of College \& Research Libraries.

\begin{abstract}
To determine which engagement factors contribute to student success at a large, public, research university in the southeast, the university library-along with representatives from Academic Affairs, Student Affairs, and other academic and support units across campus-have agreed to collaborate on the alignment and analysis of student data and to contribute their data to a repository that will enable longitudinal study. The study indicates that library, co-curricular, and extracurricular activities have a significant and positive impact on student success in terms of GPA and months to graduation. The model developed for this study is one that is easily transferable to other organizations.

\section{Introduction}

Student engagement and success are critical, with more than $40 \%$ of individuals seeking a four-year degree dropping out within six years. ${ }^{1}$ Tinto's social integration theory posits that students need integration into formal and informal academic and social systems of the university to be successful. ${ }^{2}$ Engagement strengthens students' academic intentions, goals, and institutional commitment, thereby increasing the likelihood of graduation. While universities are implementing high impact practices to engage and retain students, myriad other factors may be at play. ${ }^{3}$ Through the lens of social integration theory, formal integration may also include (1) library engagement, (2) use of student support services, and (3) participation in co- and extracurricular activities.
\end{abstract}

To determine which engagement factors contribute to student success at a large, public, research university in the southeast, the university library-along with representatives from Academic Affairs, Student Affairs, and other academic and support units across campus-have agreed to collaborate on the alignment and analysis of student data and to contribute their data to a repository that will enable longitudinal study. The joint project will not only allow the library to quantify its impact on student success, but also help university leaders identify other critical areas of student engagement.

As such, the objectives for this study are threefold and align closely with key priority areas identified in the Association of College \& Research Libraries' (ACRL) Academic Library Impact Report, which calls for librarians and information professionals to conduct research that will demonstrate library contributions to student learning and success. ${ }^{4}$ The first objective of the study, which aligns with ACRL Priority 3 , is to include library data in institutional data collection. The second objective, to quantify the library's impact on student success, aligns with ACRL Priority 4. The third objective, which follows logically from the first two, is to create a transferable model for aligning and assessing university metrics. To meet these objectives, the university library at the University of North Carolina at Charlotte (UNC Charlotte) is leading an initiative to assess student engagement and its impact on student success by forming partnerships with the university's Office of Institutional Research, the Division of Academic Affairs, the Division of Student Affairs, and other university support service units to gather and align student engagement and success data.

UNC Charlotte is an urban, research institution with the Carnegie Classification Doctoral Universities: Higher Research Activity. With an enrollment of nearly 30,000 FTE (24,000 undergraduates), UNC Charlotte has the third largest undergraduate enrollment among the 17 institutions of the University of North Carolina System (fall 2018). The university accepts $66 \%$ of applicants while incoming classes are $55 \%$ new freshmen and $45 \%$ transfers. The persistence rate is $80 \%$ for the first to the second year. The university emphasizes student participation in research with faculty and in internships in the Charlotte community. Nearly $80 \%$ of students participate in internships and other research activities. 


\section{Literature Review}

Throughout the library and information studies literature, findings from a variety of studies have shown that library usage is positively correlated with academic success. ${ }^{5}$ In a study investigating library usage patterns and academic achievement of students enrolled in nearly 200 courses at a single university, findings suggested that students who "read" more, measured in terms of borrowing books and accessing electronic resources, achieved better grades. ${ }^{6}$ Likewise, findings from a study of 8,701 library records and GPA revealed statistically significant, positive correlations between GPA and checkouts of library materials. ${ }^{7}$

Other study findings indicated that participation in library instruction is significantly related to students' GPA. ${ }^{8}$ For example, a statistically-significant increase in GPA among graduating students who were enrolled in classes that participated in at least one library instruction session $(n=1,265)$ was demonstrated over students who were enrolled in classes that were not exposed to library instruction $(n=115) .{ }^{9}$ Similarly, in a large-scale study of 42,624 students across 12 universities for the academic year 2014-2015, findings suggested that the first-year GPA for students whose courses included information literacy instruction was significantly higher than the GPA of students enrolled in courses which did not include such instruction. ${ }^{10}$

More recently, Soria, Fransen, and Nackerud conducted a series of studies in which they examined the relationships between student academic achievement (GPA, degree completion, retention, and student learning outcomes) and library usage, particularly among first-year students, as documented through a variety of variables (e.g., online databases access, electronic book usage, electronic journal logins, library website logins, material borrows, interlibrary loan borrows, library workstation logins, and engagement with library staff through instruction sessions or reference interactions) along with pre-college metrics (e.g., high school GPA, SAT/ACT scores) and demographic factors (e.g., gender, international student, race, firstgeneration college student, Pell grant, college of enrollment, first year seminar, campus housing, SAT/ACT scores, incoming college credits, and participation in a student academic success program). ${ }^{11}$ The findings from these studies revealed statistically significant regression models that predicted a variety of dependent variables, including students' academic engagement, academic skills, engagement in scholarship, GPA, continued enrollment or graduation, and learning outcomes. ${ }^{12}$ In particular, the results from two of these studies suggested that four types of library services were positively and significantly associated with students' cumulative GPA: database logins, book loans/renewals, electronic journal logins, and use of library workstations. ${ }^{13}$ The model used for Soria, Fransen, and Nackerud's 2013 and 2014 studies was particularly helpful in designing the current study. ${ }^{14}$ Extending these studies further, the present study also includes student engagement variables from other academic support units across the university, high impact practice data captured from the university's participation in the National Survey of Student Engagement (NSSE, 2014, 2016, 2018), and student affairs' engagement data to include participation in sports clubs and Greek social organizations.

The study addresses three research questions.

1. How can libraries connect their data with student outcomes?

2. What effects do libraries have on success outcomes for different types of students?

3. How can libraries supplement the data collected by other university departments to document student engagement and success?

\section{Methodology}

A two-phase, mixed model was designed to include three data collection strategies across two phases. In Phase I, researchers conducted interviews and meetings with university stakeholders to gather insights for Phase II activities. In Phase II, researchers accessed and aligned datasets and conducted statistical analyses (e.g., ANOVA, Regression) to identify significant factors between student engagement and success. The independent variables were aligned and integrated with the dependent variables to form a transferable model for longitudinal data analysis. 


\section{Phase I}

Phase I began with a single brainstorming meeting in February 2018 with the key institutional research and assessment personnel (specialists) on campus to discuss the justifications for and viability of the project. The researchers and specialists discussed how we could align data (independent variables) on individual students from many different campus entities and even more systems and connect them to the dependent variables held in the student information system (Banner). Attendees included the library dean, library head of assessment, executive director of the Office of Assessment \& Accreditation, assistant provost for institutional research, director of research compliance, associate vice chancellor for student affairs for research and systems, and divisional director of student affairs for research and assessment. The library participants were surprised that a few of the individuals had never met before we brought them together. A few months later, they are working together cohesively on a variety of campus projects. During the initial meeting, the group created a list of potential partners, established the goals for the project, identified the dependent variables of interest, and agreed on the initial data alignment and de-identification process for the pilot.

The library agreed to lead the project. The library recommended as potential partners the academic support services offered in or near the library building: Writing Resources Center, University Speaking Center, University Career Center, and University Center for Academic Excellence (tutoring, supplemental instruction, and affiliated services). We selected these partners as they are "academic support" or cocurricular services, mostly formal activities that were already collecting student identifying information during interactions. We wanted to include the most recent results from the National Survey of Student Engagement (2018) and as many Student Affairs metrics as were available in a compatible format (Greek Life and Sports participation).

The partners would extract data on interactions and participation by student identifier (student ID number or email prefix) from their respective system(s). The library's head of assessment would gather the data from the partners once they agreed to sign on to the project with one representative from each partner being added to the IRB Protocol. She would align the incoming datasets and deliver them to the assistant provost for Institutional Research, who would perform the crosswalk from the independent variables to the available dependent variables.

We wanted to connect with as many student demographic measures and indicators of student success (dependent variables) as possible (see Appendix A), but used semester and cumulative GPA and months to graduation in the initial data analysis. The assistant provost for institutional research then removed the identifiers and returned the dataset to the library's head of assessment who agreed to run the analyses for the partners.

After the initial brainstorming conversation with the statistical experts, the library conducted individual meetings with the representatives of each of the targeted partners. In each meeting, we explained the project, discussed the data the partner collected, discussed how to extract it from the system(s) used by the partner, discussed how to format it for delivery to the head of assessment, and worked to gain buy-in. Overall, getting buy-in was easy, though we had many conversations about how to protect student privacy, the benefits of the project to each partner, and how the data would be used in the aggregate. The Writing Resources Center took the most effort to persuade perhaps because they do not work with datasets, statistical tests, and analyses on a regular basis.

The partners asked a variety of questions during the interviews with the partners and provided the following responses.

Question \#1: How do we know that the student's personal information will be protected?

Your representative who has been approved through the IRB protocol will gather email usernames or student ID numbers in your software system(s) along with the independent variables during the regular conduct of your services. On a regular basis (typically the end of the semester or academic year), the representative will extract reports and/or spreadsheets and send them to the assistant provost for 
institutional research. He will load the data into the Student Information System and run aggregated reports upon request and typically for end-of-semester or -year reporting or for specific research projects.

\section{Question \#2: Who will have access to the PII?}

The Personally Identifiable Information (PII) of students (typically email username and/or student ID number) will be resident in the partner's system(s), but only available to the representative who is listed on the IRB. The partner is responsible for maintaining confidentiality of the information contained in the partner's system(s) according to campus security protocols. The assistant provost for institutional research receives data loads from each partner, makes the connections to the Student Information System, and runs the desired reports. He returns the aggregated, de-identified reports. Partners in the project will only have access to PII they interacted with as stored within their own systems and will otherwise see only deidentified data and aggregated reports.

\section{Question \#3: Who will make the crosswalks?}

The assistant provost for institutional research creates the connections from the datasets from each partner to a selected hook in the Student Information System. Only that individual knows what hook (a different identifier than the email username or student ID number provided by the partners) is used to link the records from each partner to the SIS data.

\section{Question \#4: What information do I have to provide, in what form, and to whom?}

The partner will need to present retrospective, current, and future datasets at agreed-upon dates to the assistant provost for institutional research. The dataset, typically an Excel spreadsheet extracted from the partner's software system(s), should include a column with the email username or student ID number followed by columns for each of the independent variables collected. The specific variables should be discussed in a meeting with the library's head of assessment and the assistant provost for institutional research. Additional variables can be added later.

\section{Question \#5: How will I get reports?}

The partner sets up a schedule in advance of what reports should be generated and when with the assistant provost for institutional research. The partner may work with the assistant provost for institutional research to produce reports from the partner's dataset that are not part of the current research project. A graduate assistant may be needed to produce reports if the assistant provost for institutional research is too busy.

Once it looked like we had sufficient partners to make the project viable, the Office of Research Compliance helped the researchers write the IRB application form and ensure everything related to the study and protection of student data was in place. With IRB approval, the researchers asked each partner to have the primary representative sign on to the IRB.

\section{Phase II}

In this first iteration of the project, engagement and success data has been compiled and aligned from all initial partners (see Appendix A) to include academic years 2012-2013 through 2017-2018, though there are some inconsistencies in the data contributed, as some partners did not have full datasets dating back to 2012. Overall, data from the library, the University Career Center, and the University Center for Academic Excellence was most complete, as these offices provided data for all six years of interest. The University Speaking Center provided data for the 2016-2017 and 2017-2018 academic years while the Writing Resources Center data included the 2013-2014 to 2017-2018 period. Greek organization and sports teams'/clubs' memberships were included for the two most recent academic years. NSSE data was compiled, consolidated, and included in the study for 2014, 2016, and 2018. At this point, there are over 70,000 individual student records and 375 variables included in the study. The partners plan to include new data for each semester moving forward.

The sample of data analyzed for the current study consists of student records from undergraduate students who matriculated into the university in summer or fall 2012. The sample was selected to generate a dataset 
that could answer questions related to students' engagement with the university throughout a six-year graduation window and to allow for predictions of months-to-graduation, first-year GPA (beginning of fall 2013), and cumulative GPA (beginning of fall 2018). In all, there were 4,967 viable records for analysis that met these parameters. Of these, 2,995 students were initially admitted to the university as new freshmen and 1,947 were admitted as new transfer students. From this sample, $70 \%(n=3,487)$ of the students graduated within a six-year window. A full set of frequency data related to the students' pre-college and demographic variables are outlined in Appendix B.

Regression and Analysis of Variance (ANOVA) tests were used to predict three measures of student success as defined for this study: GPA after first year of study, cumulative GPA, and months to graduation.

Significance thresholds were limited to $(p<.05)$. Stepwise multiple regression analysis was used as it allowed the researchers to explore the data for relationships when there was uncertainty as to whether relationships did, in fact, exist. ${ }^{15}$ One-way ANOVAs, a statistical test used to compare mean scores within and between groups, were calculated only for those samples meeting a sample size of at least 30, depending upon the number of groups being analyzed. Group size thresholds were established using $\mathrm{G}^{*}$ Power 3 using an a priori power analysis. ${ }^{16}$ In addition, Levene's test for homogeneity of variance was conducted for all ANOVA tests. Assumptions of homogeneity of variance (Levene's test, $p>.05$ ) were met for all groups unless otherwise noted. In cases in which assumptions of homogeneity of variance were violated, Welch's adjusted ANOVA test, a more robust test that is particularly useful with unequal sample sizes, was used in place of the traditional ANOVA $F$ test. For all significant ANOVAs that included more than two categories for a demographic variable, Fisher's Least Significant Difference (LSD) comparisons were conducted to assess where group differences occur. In cases in which assumptions of homogeneity of variance were violated and a Welch's ANOVA test was calculated instead of the traditional ANOVA $F$ test, a Games-Howell post hoc test was conducted in place of Fisher's LSD. For all significant ANOVAs, descriptive statistics, which outline means and standard deviations, are outlined in Appendix C.

\section{Results \\ Analysis of Variance}

ANOVA tests were run for all categorical variables to see if there were significant and noteworthy differences among groups related to first-year GPA, cumulative GPA, and months to graduation. These tests were conducted in the aggregate for the entire 2012-2013 sample for students who matriculated as new freshmen and for students who matriculated as new transfers. There were myriad significant ANOVAs (see Appendix D) related to cumulative GPA and months to graduation. ANOVA results relating to first-year GPA are not included, as sample sizes were too small for reliable analysis. Effect sizes, measured using eta squared $\left(\eta_{p}^{2}\right)$, largely fell into the negligible (<.01) to small (.01-.04) range, with a few bordering on medium (>.04).

Particularly noteworthy among the ANOVAs are findings that suggest that cumulative GPA differs significantly in the aggregate depending on the total number of engagements with university co-curricular and extra-curricular services included in this study (Welch's $F_{(5,1446.07)}=112.79, \mathrm{p}<.001, \eta_{p}{ }^{2}=.01$ ). Similar findings were revealed when the test was run for students who matriculated as new freshmen (Welch's $\left.F_{(5,912.146)}=20.4, \mathrm{p}<.001, \eta_{p}^{2}=.04\right)$. Post-hoc analysis revealed that students who engaged with the participating units in this study fewer than 10 times earned significantly lower GPAs than all others (Appendix D, Table 1). When broken down by particular partner, significantly higher cumulative GPAs were indicated for students who engaged more frequently with the University Career Center (Welch's $F_{(3,371.65)}=112.79, \mathrm{p}<.001, \eta_{p}{ }^{2}=.03$ ), the University Center for Academic Excellence (Welch's $F_{(4,688.07)}=8.12, \mathrm{p}<.001, \eta_{p}{ }^{2}=.01$ ), and the library (Welch's $F_{(4,2238.6)}=13.5, \mathrm{p}<.001, \eta_{p}{ }^{2}=.01$ ), both in the aggregate and for students who matriculated as new freshmen (See Appendix D, Table 1 for freshman and post-hoc results). Finally, analysis by particular library activity-participation in library instruction (Welch's $F_{(2,2568.85)}=28.47, \mathrm{p}<.001, \eta_{p}{ }^{2}=.01$ ), reservations placed for library study rooms (Welch's $F_{(3,1573.1)}=49.53, \mathrm{p}<.001, \eta_{p}{ }^{2}=.03$ ), and library book checkouts (Welch's $\left.F_{(2,1045.67)}=39.89, \mathrm{p}<.001, \eta_{p}{ }^{2}=.01\right)$ - showed significant and noteworthy findings, both in the aggregate and for students who matriculated as new freshmen (see Appendix D, Table 1 for freshman and post-hoc results). ANOVA results also revealed that cumulative GPA differed significantly depending upon the number of high impact practices a student participated in, as reported on the NSSE, both for the aggregate $\left(F_{(2,195.39)}=140.932\right.$, 
$\left.\mathrm{p}<.001, \eta_{p}{ }^{2}=.025\right)$ and for students who matriculated as new freshmen $\left(F_{(2,113.709)}=117.167, \mathrm{p}<.001, \eta_{p}{ }^{2}=.035\right)$. For students who matriculated as new transfer students, the significant ANOVA with the largest effect size related to cumulative GPA was for visits to the University Center of Academic Excellence $\left(F_{(4,199.99)}=14.84\right.$, $\left.\mathrm{p}<.001, \eta_{p}^{2}=.03\right)$.

ANOVA tests were also conducted for all categorical independent variables (Appendix A) to assess for group differences related to months to graduation. The only meaningful ANOVA related to months to graduation was for participation in high impact practices (HIPs) for students who matriculated as new freshmen (Welch's $\left.F_{(2,131.11)}=33.26, \mathrm{p}<.001, \eta_{p}{ }^{2}=.01\right)$. Post-hoc analysis revealed that students who participated in one or more HIPs graduated in significantly fewer months than those who did not participate in an HIP (see Appendix D, Table 2).

\section{Stepwise Regression}

Stepwise Regression tests revealed numerous, statistically-significant models that predicted first-year GPA (Appendix E, Table 1), cumulative GPA (Appendix E, Table 2), and months to graduation (Appendix E, Table 3), not only for the aggregate, but also for students who matriculated either as freshmen or transfer students. For each of the dependent variables, separate regression analyses were run to include:

1. Total of all engagements across partners;

2. Total engagements $\mathrm{X}$ partner;

3. Total engagements $\mathrm{X}$ specific partner activities;

4. All specific partner activities, and

a. Pre-college factors (weighted high school GPA, incoming transfer for AP credits, SAT/ACT scores, Pell grant award);

b. Demographic variables (e.g., gender);

c. Greek organization and sports clubs/team participation;

d. High impact practices (internships, study abroad, learning community, research with faculty, culminating senior experience, etc.);

1. Total library engagements;

2. Engagements in specific library activities (e.g., study room reservations, library instruction, computer logins, book checkouts, etc.);

3. Engagements in specific library activities; and

a. Pre-college factors (see Item 4);

b. Demographic variables (e.g., gender);

c. Greek organization and sports club/team participation;

d. High impact practices (internships, study abroad, learning community, research with faculty, culminating senior experience, etc.). 
Of these 64 regression tests, 62 were statistically significant $(\mathrm{p}<.05)$. The two models that were not statistically significant were related to the transfer student subset.

\section{First-Year GPA}

Overall, the models which only included university partner data (not pre-college or demographic factors), though statistically significant, predicted, at most, 3.3\% of the variance in first-year GPA. Adding in precollege and demographic variables resulted in noticeably higher ability to predict variances in GPA. All statistically-significant regression models related to first-year GPA are outlined in Appendix E, Table 1. Overall, the model that included specific partner activities along with pre-college and demographic factors for the aggregate set was the strongest $\left(F_{(6,3412)}=127.225, \mathrm{p}<.001\right)$ and explained $18.3 \%$ of the variance in firstyear GPA. This model suggests that library computer usage along with attendance at career fairs, career advising, and UCAE supplemental instruction sessions are associated with higher GPAs. The regression equation for this model was:

Predicted 1st Year GPA $=1.003+.466($ Weighted HS GPA $)+137($ Gender $(1=$ Male; $2=$ Female $))+.098(2012-$ 2013 Career Fairs $)+.047(2012-2013$ Career Advising $)+.003(2012-2013$ Library Computer Logins $)+$ .013(2012-2013 UCAE Supplemental Instruction)

\section{Cumulative GPA}

Similar to the models predicting first-year GPA, models which included pre-college and demographic factors had greater ability to explain variance in cumulative GPA. However, it should be noted that a statisticallysignificant model using only partner engagement data (no pre-college or demographic factors) was able to explain $9.6 \%$ of the variance in cumulative GPA for the new freshman subset $\left(F_{(8,2986)}=39.83, \mathrm{p}<.001\right)$. (See Appendix E, Table 2 for other significant models relating to cumulative GPA). This model suggests that engagement with specific services in the University Career Center, the library, the University Center for Academic Excellence, the Writing Resources Center, and high impact practices is positively associated with cumulative GPA. The regression equation for this model was:

Predicted cumulative GPA $=2.757+.056$ (Career Fairs $)+.092$ (Career Workshops $)+.036$ (Library Instruction) +.007 (Library Book Checkouts) +.002 (Library Study Room Reservations) +.012 (UCAESupplemental Instruction) +.139 (Total HIPs) +.035 (Writing Center Consultations)

When pre-college and other demographic factors are added into a model along with specific library activities, the model explains even more of the variance in cumulative GPA (18.3\%) for students who matriculated as freshmen $\left(F_{(9,2959)}=73.842, \mathrm{p}<.001\right)$. The regression model to predict cumulative GPA for the new freshman matriculant subset was:

Predicted cumulative GPA $=1.545+.172($ Weighted HS GPA $)+.026($ Standardized SAT $/ A C T)+.108($ Total HIPs $)+.004$ (Library Book Checkouts $)+.037$ (Library Instruction) ++.01 (UCAE-Supplemental Instruction $)+.041$ (Career Fairs) +.019(Career Advising)

This model suggests that library book checkouts, participation in library and UCAE instruction sessions, attendance at career fairs, and participation in career advising are positively associated with cumulative GPA.

\section{Months to Graduation}

Similar to the other measures of success for this study, all models run to predict months to graduation were statistically significant (see Appendix E, Table 3), with the ability to explain the variance in the months to graduation ranging from $1.3 \%$ to $42 \%$ depending upon the types of factors included. The most noteworthy of the models is for the aggregate subset with factors including specific partner activities along with pre-college and demographic factors $\left(F_{(4,3485)}=626.28, \mathrm{p}<.001\right)$. This model explained $42 \%$ of the variance in months to graduation. The regression equation for this model for transfer students was: 
Predicted months to graduation $=58.362-0.267$ (Incoming Credits) -1.837 (Gender (1=Male; 2=Female) - 0.685(Total HIPs) - 1.645(Sports Club Membership).

This model suggests that the number of incoming credits and participation in high impact practices along with a sports organization may help to decrease the months to graduation.

\section{Discussion}

The findings from the study suggest that engagement with various university resources, including the library, has a statistically-significant impact on student success across multiple analysis techniques. In addition to quantifying the library's role in student success, study findings revealed other significant, key areas of engagement for students, including those associated with the University Career Center, the University Center for Academic Excellence, the Writing Resources Center, and the University Speaking Center. These categories of engagements, along with participation in Greek organizations, sports clubs and teams, and high impact practices, all lend support to Tinto's theory of social integration, which suggests that academic, co-curricular, and extracurricular engagements all help to increase the chances of student success and the likelihood of graduation. ${ }^{17}$

Aligning co-curricular and extracurricular student engagement metrics with measures of student success can provide powerful insights to universities as they seek ways to promote deep, rich learning while increasing student retention and graduation rates. Creating a central data repository with the right structure and rapid updates would increase the ability to understand and predict student behavior. The repository should include not only measures of engagement and student success, but also pre-college and demographic variables, as the disaggregation of data is necessary to understand particular categories of student subsets. While the analysis for this study involved disaggregating data according to original admission status (freshman or transfer), it is only a first step in understanding our university population. The model developed for this study, which involved inviting other university constituents to the table to form partnerships, share ideas, make mutually-beneficial decisions, outline responsibilities, work together to identify key metrics, and collaborate to align and analyze these data is one that is easily transferable to other organizations. The power of the model will intensify as new partners are identified and brought into the study.

\section{Study Limitations}

Although every attempt was made to conduct a thorough and comprehensive exploration of the cocurricular and extracurricular factors relating to undergraduate students' engagement and success, the study was subject to numerous limitations. These limitations relate primarily to the dataset, which had many missing or inconsistent variables that had to be ignored or imputed. Transitioning from the full dataset to the portion with the most complete and reliable data actually improved our ability to explain variations in the data, despite the smaller number of records. Moving forward, the current partners now have a clearer understanding of the categories of data they need to collect and methods for doing so that will make future alignment and analysis much easier and more complete.

Through this analysis, the researchers realized the advantage of recruiting additional partners, particularly those departments or units responsible for directly managing the high impact practices across the university, including those that arrange programs for study abroad, undergraduate research, learning communities, internships, and more. The most significant limitation to the study was relying upon self-report data from the NSSE surveys related to high impact practices since completion of NSSE is voluntary and subject to significant inaccuracies inherent in self-reporting.

\section{Conclusions}

The study indicates that library, co-curricular, and extracurricular activities have a significant and positive impact on student success in terms of GPA and months to graduation. Future studies will emphasize integrating data from additional partners, more consistently gathering activity metrics, and testing other demographic and pre-college factors. With a greater variety and accuracy of data, we hope to achieve deeper 
understanding of the impact of the library and other aspects of student life on student success and graduation.

The study represents one of the first efforts documented in the library and information studies literature in which the library has taken the lead on developing a transferable model for aligning and assessing university student activity and success metrics in order to quantify the value of the academic library. Too often, we are not aware of what other units across our campuses are doing in support of our mutual goal to promote student learning, success, and graduation. By building relationships and collaborating in the development of an institutional repository of student engagement and success data, campus units may find themselves less focused on competing for valuable campus resources and more focused on working together for the future success of our students.

-Copyright 2019 Rebecca A. Croxton and Anne Cooper Moore

\section{Notes}

1. National Center for Education Statistics, Fast Facts, prepared by Institute of Education Sciences (Washington, DC: US Department of Education, 2018), https://nces.ed.gov/fastfacts/display.asp?id=40.

2. Vincent Tinto, Leaving College: Rethinking the Causes and Cures of Student Attrition, 2nd ed. (Chicago: University of Chicago Press, 1993); Vincent Tinto and Brian Pusser, Moving from Theory to Action: Building a Model of Institutional Action for Student Success (Washington, DC: NPEC, 2006).

3. George D. Kuh, Ken O'Donnell, \& Sally Reed, Ensuring Quality and Taking High-Impact Practices to Scale (Washington, DC: Association of American Colleges and Universities, 2013).

4. Association of College and Research Libraries, Academic Library Impact: Improving Practice and Essential Areas to Research, prepared by Lynn Silipigni Connaway, William Harvey, Vanessa Kitzie, and Stephanie Mikitish (Chicago: Association of College and Research Libraries, 2017), http://www.ala.org/acrl/sites/ala.org.acrl/files/content/publications/whitepapers/academiclib.pdf.

5. Deborah Goodall and David Pattern, "Academic Library Non/Low Use and Undergraduate Student Achievement: A Preliminary Report of Research in Progress," Library Management 111, no. 32 (2011): 159170; Krista M. Soria, "Factors Predicting the Importance of Libraries and Research Activities for Undergraduates," The Journal of Academic Librarianship 39, no. 6 (2013): 464-470; Krista M. Soria, Jan Fransen, and Shane Nackerud, "Library Use and Undergraduate Student Outcomes: New Evidence for Students' Retention and Academic Success," Portal: Libraries \& The Academy 13 (2013): 147-164; Krista M. Soria, Jan Fransen, and Shane Nackerud, "Stacks, Serials, Search Engines, and Students' Success: First-Year Undergraduate Students' Library Use, Academic Achievement, and Retention,” Journal of Academic Librarianship 40 (2014): 84-91; Krista M. Soria, Jan Fransen, and Shane Nackerud, "Beyond Books: The Extended Academic Benefits of Library Use for First-Year College Students," College of Research Libraries 78 (2017): 8-22; Krista M. Soria, Jan Fransen, and Shane Nackerud, "The Impact of Academic Library Resources on Undergraduates' Degree Completion," College \& Research Libraries 78 (2017): 812-823.

6. Goodall and Pattern, "Academic Library Non/Low Use," 159-170.

7. Shuh Han Rebekah Wong and T.D. Webb, "Uncovering Meaningful Correlation between Student Academic Performance and Library Material Usage," College \&t Research Libraries 72 (2011): 361-370.

8. Ula Gaha, Suzanne Hinnefeld, Catherine Pellegrino, "The Academic Library's Contribution to Student Success: Library Instruction and GPA," College \& Research Libraries 79, no. 6 (2018): 737-745; Greater Western Library Alliance, The Impact of Information Literacy Instruction on Student Success: A Multiinstitutional Investigation and Analysis, prepared by Joni Blake, Melissa Bowles-Terry, Shirlene Pearson, and Zoltan Szentkiralyi (Greater Western Library Alliance, 2017), https://www.arl.org/storage/documents/publications/The_Impact_of_Information_Literacy_Instruction _on_Student_Success_October_2017.pdf; Soria, Fransen, and Nackerud, "Library Use and Undergraduate Student Outcomes," 147-164.

9. Gaha, Hinnefeld, and Pellegrino, "The Academic Library's Contribution to Student Success," 737-745. 10. GWLC, Impact of Information Literacy Instruction on Student Success. 
11. Soria, Fransen, and Nackerud, "Library Use and Undergraduate Student Outcomes," 147-164; Soria, Fransen, and Nackerud, "Stacks, Serials, Search Engines, and Students' Success," 84-91; Soria, Fransen, and Nackerud, "Beyond Books," 8-22; Soria, Fransen, and Nackerud, "The Impact of Academic Library Resources on Undergraduates' Degree Completion," 812-823.

12. Soria, Fransen, and Nackerud, "Beyond Books," 8-22; Soria, Fransen, and Nackerud, "The Impact of Library Resources on Undergraduates' Degree Completion," 812-823; Krista M. Soria, Kate Peterson, Jan Fransen, and Shane Nackerud, "The Impact of Academic Library Resources on First-Year Students' Learning Outcomes," Research Library Issues, 29 (2017): 5-20.

13. Soria, Fransen, and Nackerud, "Beyond Books," 8-22; Soria, Fransen, and Nackerud, "The Impact of Library Resources on Undergraduates' Degree Completion," 812-823.

14. Soria, Fransen, and Nackerud, "Beyond Books," 8-22; Soria, Fransen, and Nackerud, "The Impact of Library Resources on Undergraduates' Degree Completion,” 812-823.

15. W. Paul Vogt and R. Burke Johnson, Dictionary of Statistics \& Methodology: A Nontechnical Guide for the Social $S$, 4th ed. (Los Angeles: Sage, 2011).

16. Franz Faul, Edgard Erdfelder, Axel Buchner, and Albert-Georg Lang, "Statistical Power Analyses Using G*Power 3.1: Tests for Correlation and Regression Analyses," Behavior Research Methods 41, no. 4, 11491160.

17. Tinto, Leaving College. 
Appendix A

Variables 2012-2013 to 2017-2018

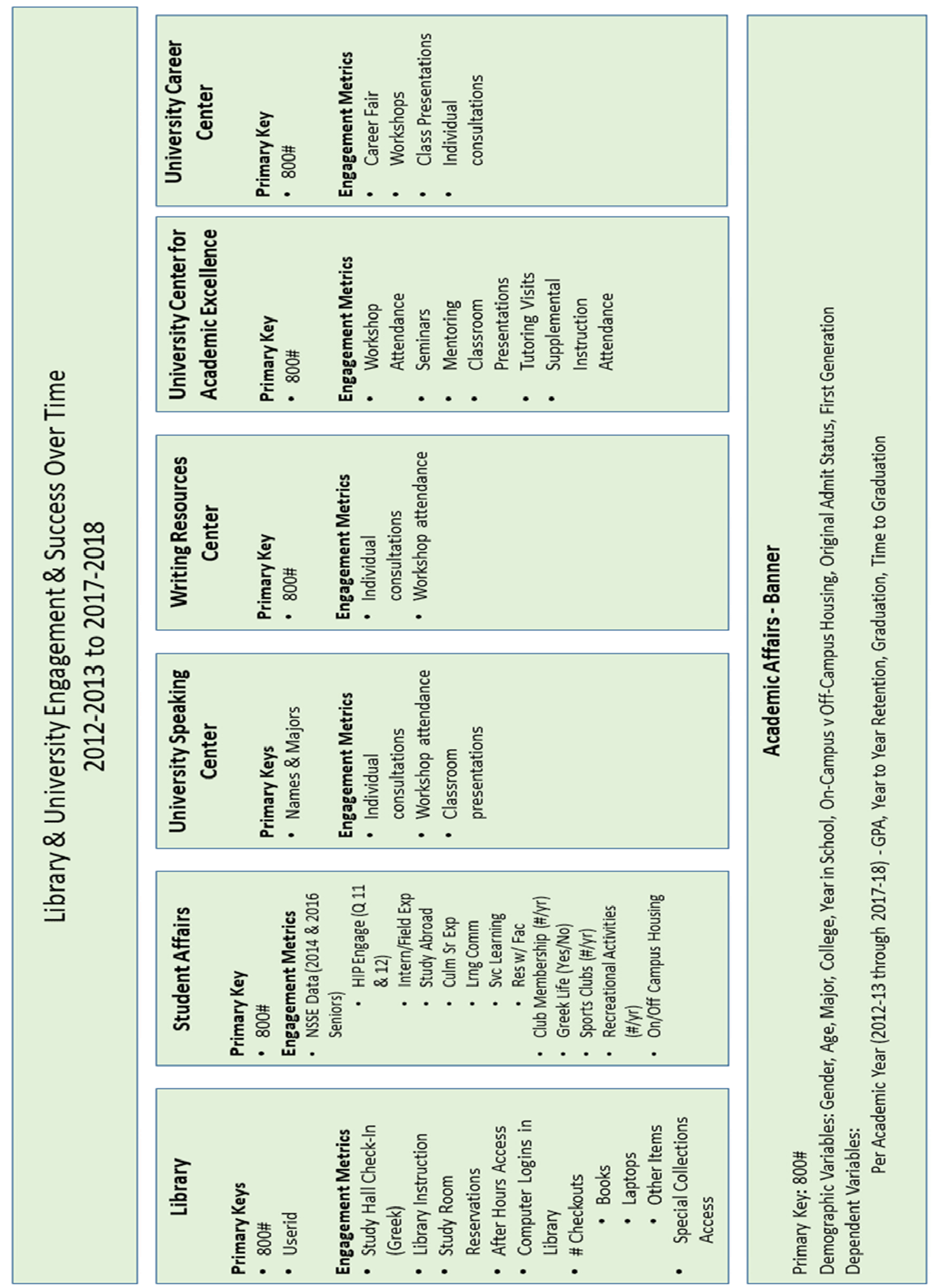


Appendix B

Participant Demographics: Summer \& Fall 2012 Undergraduate Student Matriculants

\begin{tabular}{|c|c|c|c|}
\hline Demographic & $\begin{array}{l}\text { Aggregate } \\
\text { n (\%) }\end{array}$ & $\begin{array}{l}\text { Entered as } \\
\text { Freshman } \\
\mathrm{n}(\%)\end{array}$ & $\begin{array}{l}\text { Entered as } \\
\text { Transfer } \\
\mathrm{n}(\%)\end{array}$ \\
\hline Original Admit Status & 4967 (100) & $2995(60.2)$ & $1947(39.2)$ \\
\hline \multicolumn{4}{|l|}{ Gender } \\
\hline Male & $2594(52.2)$ & $1553(51.9)$ & $1034(53.1)$ \\
\hline Female & $2373(47.8)$ & $1442(48.1)$ & $913(46.9)$ \\
\hline \multicolumn{4}{|c|}{ High School GPA (Weighted) } \\
\hline $1-2.50$ & $73(1.5)$ & $1(0.0)$ & $68(3.5)$ \\
\hline $2.51-3.00$ & $268(5.4)$ & $129(4.3)$ & $131(6.7)$ \\
\hline $3.01-3.50$ & $974(19.6)$ & $802(26.8)$ & $170(8.7)$ \\
\hline $3.51-4.00$ & $1236(25.4)$ & $1115(37.2)$ & $147(7.6)$ \\
\hline $4.01+$ & $848(17.1)$ & $766(25.6)$ & $82(4.2)$ \\
\hline \multicolumn{4}{|c|}{$\begin{array}{l}\text { HS Standardized Test Score (SAT/ACT) } \\
\text { Standardized to ACT (Max Pts Poss. 36) }\end{array}$} \\
\hline $5-15$ & $1538(31.0)$ & $343(11.5)$ & $1186(60.9)$ \\
\hline $16-20$ & $865(17.4)$ & $506(16.9)$ & $350(18.0)$ \\
\hline $21-25$ & $1948(39.9)$ & $1677(56.0)$ & $302(15.5)$ \\
\hline $26+$ & $580(11.7)$ & $469(15.7)$ & $109(5.6)$ \\
\hline \multicolumn{4}{|c|}{ Incoming Credits (Transfer, AP, etc.) } \\
\hline 0 & $1693(34.1)$ & $1680(56.1)$ & $11(0.6)$ \\
\hline $1-9$ & $784(15.8)$ & $772(25.8)$ & $12(0.6)$ \\
\hline $10-24$ & $473(9.5)$ & $338(11.3)$ & $130(6.7)$ \\
\hline $25-39$ & $584(11.8)$ & $92(3.1)$ & $484(24.9)$ \\
\hline $40-59$ & $566(11.4)$ & 49 (1.6) & $512(26.3)$ \\
\hline $60+$ & $867(17.5)$ & $64(2.1)$ & $789(41.0)$ \\
\hline \multicolumn{4}{|l|}{ Months to Graduation } \\
\hline $9-19$ & $32(0.9)$ & -- & $32(2.2)$ \\
\hline $20-35$ & 799 (22.9) & $48(2.3)$ & $747(52.4)$ \\
\hline $36-48$ & $1450(41.5)$ & $1025(50.1)$ & $419(29.4)$ \\
\hline $49-60$ & 973 (27.9) & $791(38.7)$ & $176(12.3)$ \\
\hline
\end{tabular}




\begin{tabular}{|c|c|c|c|}
\hline Demographic & $\begin{array}{l}\text { Aggregate } \\
\text { n (\%) }\end{array}$ & $\begin{array}{l}\text { Entered as } \\
\text { Freshman } \\
\mathrm{n}(\%)\end{array}$ & $\begin{array}{l}\text { Entered as } \\
\text { Transfer } \\
\mathrm{n}(\%)\end{array}$ \\
\hline $61+$ & $236(6.8)$ & $181(8.9)$ & $52(3.6)$ \\
\hline \multicolumn{4}{|l|}{ Pell Recipient } \\
\hline Yes & $2514(50.6)$ & $1365(45.6)$ & $1138(58.4)$ \\
\hline No & $2453(49.4)$ & $1630(54.4)$ & $809(41.6)$ \\
\hline \multicolumn{4}{|c|}{ Sports Club or Team } \\
\hline Yes & $171(3.4)$ & $137(4.6)$ & $33(1.7)$ \\
\hline No & $4796(96.6)$ & $2858(95.4)$ & $1914(98.3)$ \\
\hline \multicolumn{4}{|c|}{ Greek Organization Membership } \\
\hline Yes & $449(9.0)$ & $403(13.5)$ & $45(2.3)$ \\
\hline No & $4518(91.0)$ & $2592(86.5)$ & $1902(97.7)$ \\
\hline \multicolumn{4}{|c|}{ Completed 1 or More Internships (NSSE) } \\
\hline Yes & $165(3.3)$ & $127(4.2)$ & $35(1.8)$ \\
\hline No & $4802(96.6)$ & $2868(95.7)$ & $1912(98.2)$ \\
\hline \multicolumn{4}{|c|}{ Learning Community Participant (NSSE) } \\
\hline Yes & $88(1.8)$ & $72(2.4)$ & $14(0.7)$ \\
\hline No & $4879(98.2)$ & $2923(97.6)$ & $1933(99.3)$ \\
\hline \multicolumn{4}{|c|}{ Conducted Research w/ Faculty (NSSE) } \\
\hline Yes & $74(1.5)$ & $55(1.8)$ & $18(0.9)$ \\
\hline No & $4893(98.5)$ & $2940(98.2)$ & $1929(99.1)$ \\
\hline \multicolumn{4}{|c|}{ Participated in a Study Abroad (NSSE) } \\
\hline Yes & $44(0.9)$ & $32(1.1)$ & $11(0.6)$ \\
\hline No & $4923(99.1)$ & $2963(98.9)$ & $1936(99.4)$ \\
\hline \multicolumn{4}{|c|}{ Completed Culm. Senior Exper. (NSSE) } \\
\hline Yes & $162(3.3)$ & $126(4.2)$ & $36(1.8)$ \\
\hline No & $4805(96.7)$ & $2869(98.8)$ & $1911(98.2)$ \\
\hline
\end{tabular}


Appendix C

Table 1: Cumulative GPA (Fall 2018)-Descriptive Statistics for Variables with Significant ANOVAs

\begin{tabular}{|c|c|c|c|c|c|c|c|c|c|}
\hline \multirow[t]{2}{*}{ Grouping Variable } & \multicolumn{3}{|c|}{ Aggregate } & \multicolumn{3}{|c|}{ Entered as Freshman } & \multicolumn{3}{|c|}{ Entered as Transfer } \\
\hline & $\mathbf{N}$ & Mean & $\begin{array}{l}\text { Std } \\
\text { Dev }\end{array}$ & $\mathbf{N}$ & Mean & $\begin{array}{l}\text { Std } \\
\text { Dev }\end{array}$ & $\mathbf{N}$ & Mean & $\begin{array}{l}\text { Std } \\
\text { Dev }\end{array}$ \\
\hline Aggregate & 4967 & 2.91 & .65 & 2996 & 2.93 & .63 & 1947 & 2.88 & .67 \\
\hline \multicolumn{10}{|l|}{$\begin{array}{l}\text { Total Engagements } \\
\text { Overall }\end{array}$} \\
\hline $1-9$ & 1417 & 2.80 & .75 & 747 & 2.71 & .75 & 663 & 2.89 & .74 \\
\hline $10-24$ & 1310 & 2.93 & .64 & 809 & 2.97 & .60 & 496 & 2.86 & .68 \\
\hline $25-49$ & 1048 & 2.93 & .61 & 686 & 2.98 & .58 & 356 & 2.84 & .64 \\
\hline $50-74$ & 463 & 3.02 & .56 & 294 & 3.06 & .55 & 168 & 2.95 & .56 \\
\hline $75-99$ & 263 & 2.95 & 55 & 168 & 3.03 & .51 & 93 & 2.80 & .60 \\
\hline $100+$ & 466 & 3.00 & .53 & 292 & 3.04 & .52 & 171 & 2.94 & .55 \\
\hline \multicolumn{10}{|l|}{$\begin{array}{l}\text { Career Center } \\
\text { Totals }\end{array}$} \\
\hline 0 & 2214 & 279 & .72 & 1218 & 2.78 & .71 & 987 & 2.81 & .74 \\
\hline $1-4$ & 2236 & 2.97 & .59 & 1432 & 2.99 & .57 & 793 & 2.93 & .62 \\
\hline $5-10$ & 435 & 3.13 & .49 & 290 & 3.20 & .45 & 141 & 3.03 & .52 \\
\hline $11+$ & 82 & 3.09 & .41 & 55 & 3.17 & 3.6 & 26 & 2.96 & .46 \\
\hline \multicolumn{10}{|l|}{$\begin{array}{l}\text { Univ Ctr for Acad } \\
\text { Excellence }\end{array}$} \\
\hline 0 & 1524 & 2.96 & .69 & 621 & 2.88 & .68 & 897 & 3.00 & .69 \\
\hline $1-4$ & 2179 & 2.86 & .64 & 1501 & 2.90 & .64 & 668 & 2.77 & .64 \\
\hline $5-10$ & 706 & 2.93 & .57 & 504 & 3.00 & .54 & 196 & 2.78 & .61 \\
\hline $11-25$ & 448 & 2.87 & .67 & 293 & 2.96 & .66 & 153 & 2.72 & .66 \\
\hline $26+s$ & 110 & 2.09 & .56 & 76 & 3.20 & .55 & 33 & 2.83 & .49 \\
\hline \multicolumn{10}{|l|}{ Writing Center } \\
\hline 0 & 4583 & 2.89 & 66 & 2768 & 2.90 & .64 & 1794 & 2.86 & .68 \\
\hline 1 & 228 & 3.06 & .52 & 140 & 3.13 & .49 & 85 & 2.95 & .54 \\
\hline $2+$ & 156 & 3.21 & .49 & 87 & 3.32 & .42 & 68 & 3.06 & .54 \\
\hline \multicolumn{10}{|l|}{$\begin{array}{l}\text { High Impact } \\
\text { Practices }\end{array}$} \\
\hline 0 HIPs & 4703 & 2.88 & .65 & 2811 & 2.90 & .63 & 1868 & 2.86 & .67 \\
\hline 1-2 HIPs & 129 & 3.20 & .48 & 75 & 3.28 & .42 & 54 & 3.09 & .54 \\
\hline
\end{tabular}




\begin{tabular}{|c|c|c|c|c|c|c|c|c|c|}
\hline \multirow[t]{2}{*}{ Grouping Variable } & \multicolumn{3}{|c|}{ Aggregate } & \multicolumn{3}{|c|}{ Entered as Freshman } & \multicolumn{3}{|c|}{ Entered as Transfer } \\
\hline & $\mathbf{N}$ & Mean & $\begin{array}{l}\text { Std } \\
\text { Dev }\end{array}$ & $\mathbf{N}$ & Mean & $\begin{array}{l}\text { Std } \\
\text { Dev }\end{array}$ & $\mathbf{N}$ & Mean & $\begin{array}{l}\text { Std } \\
\text { Dev }\end{array}$ \\
\hline 3-6 HIPs & 135 & 3.45 & .41 & 109 & 3.46 & .41 & 25 & 3.43 & .38 \\
\hline \multicolumn{10}{|l|}{$\begin{array}{l}\text { Sports Club } \\
\text { Membership }\end{array}$} \\
\hline Yes & 171 & 2.91 & .53 & 137 & 2.96 & .53 & 33 & 2.70 & .49 \\
\hline No & 4796 & 2.91 & .65 & 2858 & 2.92 & .64 & 1914 & 2.88 & .67 \\
\hline \multicolumn{10}{|l|}{$\begin{array}{l}\text { Greek Life } \\
\text { Membership }\end{array}$} \\
\hline Yes & 449 & 3.08 & .43 & 403 & 3.10 & .42 & 45 & 2.91 & .45 \\
\hline No & 4518 & 2.89 & .67 & 2592 & 2.90 & .66 & 1902 & 2.87 & .68 \\
\hline \multicolumn{10}{|l|}{$\begin{array}{l}\text { Library Total } \\
\text { Engagements }\end{array}$} \\
\hline $0-2$ & 843 & 2.76 & .78 & 439 & 2.63 & .79 & 400 & 2.90 & .76 \\
\hline $3-9$ & 1110 & 2.88 & .66 & 660 & 2.89 & .65 & 446 & 2.87 & .68 \\
\hline $10-24$ & 1145 & 2.93 & .64 & 712 & 2.99 & .59 & 427 & 2.84 & .69 \\
\hline $25-74$ & 1255 & 2.97 & .57 & 803 & 3.02 & .55 & 445 & 2.88 & .60 \\
\hline $75^{+}$ & 614 & 2.98 & .55 & 382 & 3.03 & .52 & 229 & 2.91 & .59 \\
\hline \multicolumn{10}{|l|}{$\begin{array}{l}\text { Library Study } \\
\text { Room Reservations }\end{array}$} \\
\hline 0 Reserv & 2645 & 2.81 & .70 & 1448 & 2.80 & .69 & 1183 & 2.84 & .71 \\
\hline 1-5 Reserv & 1201 & 2.97 & .57 & 776 & 3.00 & .56 & 421 & 2.93 & .60 \\
\hline 6-15 Reserv & 612 & 3.01 & .57 & 410 & 3.08 & .53 & 199 & 2.87 & .63 \\
\hline $16+$ Reserv & 509 & 3.11 & .52 & 361 & 3.12 & .53 & 144 & 3.07 & .52 \\
\hline \multicolumn{10}{|l|}{$\begin{array}{l}\text { Library Book } \\
\text { Checkouts }\end{array}$} \\
\hline 0 & 3755 & 2.87 & .67 & 2175 & 2.87 & .65 & 1567 & 2.86 & .69 \\
\hline $1-2$ & 473 & 2.96 & .58 & 315 & 3.00 & .58 & 152 & 2.86 & .56 \\
\hline $3+$ & 739 & 3.07 & .55 & 505 & 3.11 & .54 & 228 & 2.99 & .57 \\
\hline \multicolumn{10}{|l|}{$\begin{array}{l}\text { Library } \\
\text { Instruction }\end{array}$} \\
\hline 0 Classes & 2521 & 2.85 & .69 & 1236 & 2.88 & .69 & 1274 & 2.82 & .69 \\
\hline 1 Class & 1486 & 2.93 & .61 & 1025 & 2.90 & .61 & 455 & 2.99 & .60 \\
\hline $2+$ Classes & 960 & 3.02 & .58 & 734 & 3.04 & .55 & 218 & 2.98 & .65 \\
\hline
\end{tabular}




\begin{tabular}{|c|c|c|c|c|c|c|c|c|c|}
\hline \multirow[t]{2}{*}{ Grouping Variable } & \multicolumn{3}{|c|}{ Aggregate } & \multicolumn{3}{|c|}{ Entered as Freshman } & \multicolumn{3}{|c|}{ Entered as Transfer } \\
\hline & $\mathbf{N}$ & Mean & $\begin{array}{l}\text { Std } \\
\text { Dev }\end{array}$ & $\mathbf{N}$ & Mean & $\begin{array}{l}\text { Std } \\
\text { Dev }\end{array}$ & $\mathbf{N}$ & Mean & $\begin{array}{l}\text { Std } \\
\text { Dev }\end{array}$ \\
\hline \multicolumn{10}{|l|}{$\begin{array}{l}\text { Library } \\
\text { Computers-Total } \\
\text { Logins }\end{array}$} \\
\hline 0 Logins & 724 & 2.88 & .76 & 395 & 2.76 & .78 & 326 & 3.01 & .71 \\
\hline 1-10 Login & 2165 & 2.92 & .66 & 1360 & 2.94 & .64 & 794 & 2.87 & .69 \\
\hline 11-30 Logins & 1120 & 2.89 & .61 & 692 & 2.95 & .57 & 422 & 2.80 & .68 \\
\hline $31+$ Logins & 958 & 2.93 & .57 & 548 & 2.98 & .56 & 405 & 2.86 & .58 \\
\hline \multicolumn{10}{|l|}{ Libary EZ Proxy } \\
\hline 0 Logins & 4540 & 2.89 & .66 & 2709 & 2.92 & .64 & 1809 & 2.86 & .66 \\
\hline 1-5 Logins & 239 & 2.98 & .56 & 169 & 2.94 & .56 & 69 & 3.07 & .56 \\
\hline $6+$ Logins & 188 & 3.10 & .55 & 117 & 3.06 & .55 & 69 & 3.20 & .52 \\
\hline \multicolumn{10}{|l|}{$\begin{array}{l}\text { Library Laptop } \\
\text { Checkouts }\end{array}$} \\
\hline 0 Checkouts & 4110 & 2.91 & .67 & 2416 & 2.92 & .66 & 1678 & 2.88 & .69 \\
\hline 1 Checkout & 297 & 2.96 & .55 & 196 & 2.97 & .56 & 99 & 2.94 & .54 \\
\hline $2+$ Checkouts & 560 & 2.88 & .53 & 383 & 2.94 & .51 & 170 & 2.77 & .54 \\
\hline \multicolumn{10}{|l|}{$\begin{array}{l}\text { Library After } \\
\text { Hours Access }\end{array}$} \\
\hline 0 Swipes & 4487 & 2.91 & .66 & 2615 & 2.93 & .65 & 1850 & 2.88 & .68 \\
\hline 1 Swipe & 198 & 2.92 & .50 & 154 & 2.99 & .47 & 43 & 2.66 & .52 \\
\hline $2+$ Swipes & 282 & 2.87 & .52 & 226 & 2.88 & .50 & 54 & 2.82 & .59 \\
\hline
\end{tabular}


Table 2: Months to Graduation-Descriptive Statistics for Variables with Significant ANOVAs

\begin{tabular}{|c|c|c|c|c|c|c|c|c|c|}
\hline \multirow[t]{2}{*}{ Grouping Variable } & \multicolumn{3}{|c|}{ Aggregate } & \multicolumn{3}{|c|}{ Entered as Freshman } & \multicolumn{3}{|c|}{ Entered as Transfer } \\
\hline & $\mathbf{N}$ & Mean & $\begin{array}{l}\text { Std } \\
\text { Dev }\end{array}$ & $\mathbf{N}$ & Mean & $\begin{array}{l}\text { Std } \\
\text { Dev }\end{array}$ & $\mathbf{N}$ & Mean & $\begin{array}{l}\text { Std } \\
\text { Dev }\end{array}$ \\
\hline Aggregate & 3940 & 45.41 & 1167 & 2045 & 50.99 & 7.43 & 1426 & 37.38 & 11.98 \\
\hline \multicolumn{10}{|l|}{$\begin{array}{l}\text { Total Engagements } \\
\text { Overall }\end{array}$} \\
\hline $1-9$ & 786 & 41.37 & 11.90 & 339 & 49.48 & .731 & 442 & 35.16 & 11.03 \\
\hline $10-24$ & 941 & 45.23 & 11.47 & 574 & 50.53 & 6.91 & 363 & 36.79 & 12.20 \\
\hline $25-49$ & 787 & 46.59 & 11.19 & 518 & 50.93 & 7.77 & 263 & 37.95 & 11.85 \\
\hline $50-74$ & 383 & 46.74 & 10.89 & 238 & 51.01 & 6.84 & 145 & 39.73 & 12.56 \\
\hline $75-99$ & 211 & 48.07 & 10.91 & 137 & 52.43 & 7.27 & 72 & 39.57 & 11.71 \\
\hline $100+$ & 382 & 48.91 & 11.53 & 239 & 53.39 & 8.00 & 141 & 41.25 & 12.61 \\
\hline \multicolumn{10}{|l|}{$\begin{array}{l}\text { Career Center } \\
\text { Totals }\end{array}$} \\
\hline 0 & 1279 & 43.53 & 12.27 & 628 & 50.56 & 7.88 & 645 & 36.67 & 11.95 \\
\hline $1-4$ & 1739 & 46.26 & 11.30 & 1100 & 51.13 & 7.1 & 629 & 3767 & 11.91 \\
\hline $5-10$ & 394 & 47.04 & 10.84 & 263 & 51.17 & 6.97 & 128 & 38.51 & 12.27 \\
\hline $11+$ & 78 & 48.91 & 9.36 & 54 & 51.66 & 6.33 & 24 & 47.72 & 11.96 \\
\hline \multicolumn{10}{|l|}{$\begin{array}{l}\text { Univ Ctr for Acad } \\
\text { Excellence }\end{array}$} \\
\hline 0 & 1072 & 40.49 & 13.26 & 385 & 50.76 & 8.63 & 681 & 34.67 & 11.86 \\
\hline $1-4$ & 1496 & 46.99 & 10.51 & 1012 & 50.87 & 7.22 & 476 & 38.65 & 11.52 \\
\hline $5-10$ & 527 & 48.32 & 9.26 & 386 & 51.03 & 6.68 & 137 & 40.69 & 11.22 \\
\hline $11-25$ & 310 & 48.67 & 9.56 & 201 & 51.25 & 6.97 & 108 & 43.71 & 11.54 \\
\hline $26+$ & 85 & 49.63 & 10.43 & 61 & 52.77 & 8.53 & 24 & 41.65 & 10.71 \\
\hline \multicolumn{10}{|l|}{ Writing Center } \\
\hline 0 & 3139 & 45.32 & 11.77 & 1837 & 51.08 & 7.46 & 1286 & 37.05 & 11.88 \\
\hline 1 & 203 & 46.79 & 10.82 & 125 & 50.27 & 7.64 & 76 & 41.26 & 12.86 \\
\hline $2+$ & 148 & 45.31 & 10.63 & 83 & 49.67 & 6.13 & 64 & 39.35 & 12.13 \\
\hline \multicolumn{10}{|l|}{$\begin{array}{l}\text { High Impact } \\
\text { Practices }\end{array}$} \\
\hline 0 HIPs & 3243 & 45.43 & 11.84 & 1870 & 51.23 & 7.55 & 1355 & 37.39 & 11.99 \\
\hline 1-2 HIPs & 119 & 44.96 & 10.36 & 70 & 49.27 & 6.29 & 49 & 38.81 & 11.90 \\
\hline
\end{tabular}




\begin{tabular}{|c|c|c|c|c|c|c|c|c|c|}
\hline \multirow[t]{2}{*}{ Grouping Variable } & \multicolumn{3}{|c|}{ Aggregate } & \multicolumn{3}{|c|}{ Entered as Freshman } & \multicolumn{3}{|c|}{ Entered as Transfer } \\
\hline & $\mathbf{N}$ & Mean & $\begin{array}{l}\text { Std } \\
\text { Dev }\end{array}$ & $\mathbf{N}$ & Mean & $\begin{array}{l}\text { Std } \\
\text { Dev }\end{array}$ & $\mathbf{N}$ & Mean & $\begin{array}{l}\text { Std } \\
\text { Dev }\end{array}$ \\
\hline 3-6 HIPs & 128 & 45.30 & 8.06 & 105 & 47.62 & 4.28 & 22 & 33.87 & 11.62 \\
\hline \multicolumn{10}{|l|}{$\begin{array}{l}\text { Sports Club } \\
\text { Membership }\end{array}$} \\
\hline Yes & 141 & 50.19 & 9.52 & 114 & 52.04 & 8.52 & 26 & 42.16 & 9.79 \\
\hline No & 3349 & 45.21 & 11.71 & 1931 & 50.91 & 7.35 & 1400 & 37.29 & 12.01 \\
\hline \multicolumn{10}{|l|}{$\begin{array}{l}\text { Greek Life } \\
\text { Membership }\end{array}$} \\
\hline Yes & 421 & 50.13 & 6.89 & 378 & 50.72 & 6.09 & 43 & 44.94 & 10.52 \\
\hline No & 3069 & 44.76 & 12.04 & 1667 & 51.03 & 7.70 & 1383 & 37.15 & 11.95 \\
\hline \multicolumn{10}{|l|}{$\begin{array}{l}\text { Library Total } \\
\text { Engagements }\end{array}$} \\
\hline $0-2$ & 428 & 41.40 & 11.62 & 170 & 49.59 & 6.46 & 256 & 35.97 & 10.71 \\
\hline $3-9$ & 723 & 43.98 & 11.73 & 401 & 50.08 & 6.96 & 318 & 36.31 & 12.06 \\
\hline $10-24$ & 850 & 45.38 & 11.36 & 529 & 50.41 & 7.07 & 317 & 36.94 & 12.17 \\
\hline $25-74$ & 991 & 46.59 & 11.28 & 633 & 51.19 & 7.48 & 351 & 38.16 & 12.06 \\
\hline $75^{+}$ & 498 & 48.62 & 11.68 & 312 & 53.40 & 7.92 & 184 & 40.45 & 12.53 \\
\hline \multicolumn{10}{|l|}{$\begin{array}{l}\text { Library Study Room } \\
\text { Reservations }\end{array}$} \\
\hline 0 Reserv & 1605 & 43.91 & 12.23 & 769 & 50.98 & 7.94 & 801 & 36.86 & 11.69 \\
\hline 1-5 Reserv & 939 & 46.27 & 11.36 & 597 & 50.99 & 6.91 & 338 & 37.86 & 12.75 \\
\hline 6-15 Reserv & 512 & 46.35 & 11.00 & 344 & 50.64 & 7.17 & 165 & 37.14 & 11.87 \\
\hline $16+$ Reserv & 434 & 47.99 & 10.15 & 308 & 51.30 & 7.30 & 122 & 39.82 & 11.66 \\
\hline \multicolumn{10}{|l|}{$\begin{array}{l}\text { Library Book } \\
\text { Checkouts }\end{array}$} \\
\hline 0 & 2465 & 44.07 & 12.01 & 1354 & 50.66 & 7.23 & 1102 & 35.94 & 11.80 \\
\hline $1-2$ & 395 & 48.85 & 9.72 & 262 & 51.84 & 7.60 & 128 & 42.93 & 10.69 \\
\hline $3+$ & 630 & 48.47 & 10.21 & 429 & 51.44 & 7.86 & 196 & 41.88 & 11.70 \\
\hline \multicolumn{10}{|l|}{ Library Instruction } \\
\hline 0 Classes & 1626 & 43.42 & 12.23 & 747 & 50.53 & 7.42 & 873 & 37.37 & 12.28 \\
\hline 1 Class & 1060 & 46.30 & 11.46 & 692 & 51.30 & 7.39 & 363 & 36.74 & 11.81 \\
\hline $2+$ Classes & 804 & 48.25 & 9.94 & 606 & 51.15 & 7.47 & 190 & 38.66 & 10.84 \\
\hline
\end{tabular}




\begin{tabular}{|c|c|c|c|c|c|c|c|c|c|}
\hline \multirow[t]{2}{*}{ Grouping Variable } & \multicolumn{3}{|c|}{ Aggregate } & \multicolumn{3}{|c|}{ Entered as Freshman } & \multicolumn{3}{|c|}{ Entered as Transfer } \\
\hline & $\mathbf{N}$ & Mean & $\begin{array}{l}\text { Std } \\
\text { Dev }\end{array}$ & $\mathbf{N}$ & Mean & $\begin{array}{l}\text { Std } \\
\text { Dev }\end{array}$ & $\mathbf{N}$ & Mean & $\begin{array}{l}\text { Std } \\
\text { Dev }\end{array}$ \\
\hline \multicolumn{10}{|l|}{$\begin{array}{l}\text { Library } \\
\text { Computers-Total }\end{array}$} \\
\hline 0 Logins & 443 & 42.86 & 11.60 & 206 & 49.21 & 7.13 & 235 & 37.33 & 11.96 \\
\hline 1-10 Logins & 1477 & 45.23 & 11.33 & 903 & 50.49 & 7.04 & 566 & 36.81 & 11.79 \\
\hline 11-30 Logins & 826 & 46.09 & 11.74 & 516 & 51.40 & 7.68 & 305 & 36.94 & 11.77 \\
\hline 31+ Logins & 744 & 46.53 & 12.07 & 420 & 52.35 & 7.78 & 320 & 38.83 & 12.47 \\
\hline \multicolumn{10}{|l|}{ Libary EZ Proxy } \\
\hline 0 Logins & 3195 & 44.64 & 11.12 & 1845 & 50.26 & 6.73 & 1333 & 36.83 & 11.31 \\
\hline 1-5 Logins & 161 & 54.10 & 12.73 & 116 & 56.83 & 9.59 & 45 & 47.08 & 16.71 \\
\hline $6+$ Logins & 134 & 53.33 & 15.40 & 84 & 58.66 & 10.23 & 48 & 43.52 & 18.20 \\
\hline \multicolumn{10}{|l|}{$\begin{array}{l}\text { Library Laptop } \\
\text { Checkouts }\end{array}$} \\
\hline 0 Checkouts & 2785 & 44.41 & 11.98 & 1566 & 50.65 & 7.38 & 1206 & 36.28 & 11.94 \\
\hline 1 Checkout & 246 & 48.21 & 9.34 & 160 & 51.11 & 7.61 & 85 & 42.77 & 9.96 \\
\hline $2+$ Checkouts & 459 & 49.98 & 9.33 & 319 & 52.51 & 7.38 & 135 & 43.81 & 10.59 \\
\hline \multicolumn{10}{|l|}{$\begin{array}{l}\text { Library After Hours } \\
\text { Access }\end{array}$} \\
\hline 0 Swipes & 3091 & 44.47 & 11.71 & 1725 & 50.48 & 7.29 & 1350 & 36.76 & 11.80 \\
\hline 1 Swipe & 165 & 50.43 & 8.63 & 131 & 51.40 & 7.33 & 33 & 46.10 & 11.54 \\
\hline $2+$ Swipes & 234 & 54.31 & 7.74 & 189 & 55.23 & 7.40 & 43 & 50.15 & 7.88 \\
\hline
\end{tabular}




\section{Appendix D}

Table 1: Cumulative GPA (Fall 2018)-Analysis of Variance-Significant Results

\begin{tabular}{|c|c|c|c|c|c|}
\hline Independent Variables & $F$ & $d f$ & Sig. $(p)$ & $\begin{array}{l}\text { Effect } \\
\left(\eta_{p}^{2}\right)\end{array}$ & $\begin{array}{l}\text { Post Hoc } \\
\text { Sig Results* }\end{array}$ \\
\hline \multicolumn{6}{|l|}{ Aggregate } \\
\hline Total Engagements Overall & $112.79 * *$ & $5,1446.07$ & $<.001$ & .01 & $\begin{array}{l}10-24>1-9 \text { *** } \\
25-49>1-9 \\
50-74>1-9 \\
75-99>1-9 \\
110+>1-9\end{array}$ \\
\hline Career Center Total & $64.49^{* *}$ & $3,371.65$ & $<.001$ & .03 & $\begin{array}{l}1-4>0 \text { *** } \\
5-9>0 \\
5-9>1-4 \\
10+>0 \\
10+>1-4\end{array}$ \\
\hline Univ Center for Acad Ex & $8.12 * *$ & $4,688.07$ & $<.001$ & .01 & $\begin{array}{l}0>1-4^{* * *} \\
5-10>1-4 \\
26+>1-4 \\
26+>11-25\end{array}$ \\
\hline Writing Center & $39.39 * *$ & $2,278.02$ & $<.001$ & .01 & $\begin{array}{l}1>0 * * * \\
2+>0 \\
2+>1\end{array}$ \\
\hline High Impact Practices & $140.932^{* *}$ & $2,195.39$ & $<.001$ & .025 & $\begin{array}{l}1-2>0 \text { *** } \\
3-6>0 \\
3-6>1-2\end{array}$ \\
\hline Greek Life Membership & $71.27^{* *}$ & $1,684.87$ & $<.001$ & .01 & $\mathrm{~N} / \mathrm{A}$ \\
\hline Library Total Engagements & $13.50^{* *}$ & $4,2238.60$ & $<.001$ & .01 & $\begin{array}{l}3-9>0-2 * * * \\
10-24>0-2 \\
25-74>0-2 \\
75+>0-2 \\
25-74>3-9 \\
75+>3-9\end{array}$ \\
\hline Library Study Room Reserv & $49.53^{* *}$ & $3,1573.10$ & $<.001$ & .03 & $\begin{array}{l}1-5>0 * * * \\
6-15>0 \\
16+>0 \\
16+>1-5 \\
16+>6-15\end{array}$ \\
\hline Library Book Checkouts & $39.89 * *$ & $2,1045.67$ & $<.001$ & .01 & $\begin{array}{l}1-2>0 * * * \\
3+>0 \\
3+>1-2\end{array}$ \\
\hline Library Instruction & $28.47^{* *}$ & $2,2568.85$ & $<.001$ & .01 & $\begin{array}{l}1>0 * * * \\
2+>0 \\
2+>1\end{array}$ \\
\hline Library EZ Proxy & $14.52^{* *}$ & $2,313.94$ & $<.001$ & .004 & $6+>0 * * *$ \\
\hline
\end{tabular}




\begin{tabular}{|c|c|c|c|c|c|}
\hline Independent Variables & $F$ & $d f$ & Sig. $(p)$ & $\begin{array}{l}\text { Effect } \\
\left(\boldsymbol{n}_{p}^{2}\right)\end{array}$ & $\begin{array}{l}\text { Post Hoc } \\
\text { Sig Results* }\end{array}$ \\
\hline \multicolumn{6}{|l|}{ Entered as New Freshman } \\
\hline Total Engagements Overall & $20.4^{* *}$ & $5,912.146$ & $<.001$ & .04 & $\begin{array}{l}10-24>1-9^{* * *} \\
25-49>1-9 \\
50-74>1-9 \\
75-99>1-9 \\
100+>1-9\end{array}$ \\
\hline Career Center Total & $59.25^{* *}$ & $3,253.16$ & $<.001$ & .05 & $\begin{array}{l}1-4>0^{* * *} \\
5-9>0 \\
5-9>1-4 \\
10+>0 \\
10+>1-4\end{array}$ \\
\hline Univ Center for Acad Ex & $7.78^{* *}$ & $4,449.23$ & $<.001$ & .01 & $\begin{array}{l}5-10>0 * * * \\
5-10>1-4 \\
26+>0 \\
26+>1-4 \\
26+>5-10 \\
26+>11-25\end{array}$ \\
\hline Writing Center & $50.74^{* *}$ & $2,162.9$ & $<.001$ & .02 & $\begin{array}{l}1>0 * * * \\
2+>0 \\
2+>1\end{array}$ \\
\hline High Impact Practices & $117.167^{* *}$ & $2,133.709$ & $<.001$ & .035 & $\begin{array}{l}1-2>0^{* * *} \\
3-6>0 \\
3-6>1-2\end{array}$ \\
\hline Greek Life Membership & $66.65^{* *}$ & $1,747.97$ & $<.001$ & .01 & N/A \\
\hline Library Total Engagements & $25.40^{* *}$ & $4,1309.5$ & $<.001$ & .04 & $\begin{array}{l}3-9>0-2^{* * *} \\
10-24>0-2 \\
25-74>0-2 \\
75+>0-2 \\
10-24>3-9 \\
25-74>3-9 \\
75+>3-9\end{array}$ \\
\hline Library Study Room Reserv & $46.55^{* *}$ & $3,1102.4$ & $<.001$ & .04 & $\begin{array}{l}1-5>0 * * * \\
6-15>0 \\
16+>0 \\
16+>1-5\end{array}$ \\
\hline Library Book Checkouts & $38.28^{* *}$ & $2,718.4$ & $<.001$ & .02 & $\begin{array}{l}1-2>0^{* * * *} \\
3+>0 \\
3+>1-2\end{array}$ \\
\hline Library Instruction & $18.04^{* *}$ & $2,1844.3$ & $<.001$ & .01 & $\begin{array}{l}2+>0 * * * \\
2+>1\end{array}$ \\
\hline Library Computer Logins & $8.10^{* *}$ & $3,1178.24$ & $<.001$ & .01 & $\begin{array}{l}1-10>0^{* * *} \\
11-30>0 \\
31+>0\end{array}$ \\
\hline
\end{tabular}




\begin{tabular}{|c|c|c|c|c|c|}
\hline Independent Variables & $F$ & $d f$ & Sig. $(p)$ & $\begin{array}{l}\text { Effect } \\
\left(\eta_{p}^{2}\right)\end{array}$ & $\begin{array}{l}\text { Post Hoc } \\
\text { Sig Results* }\end{array}$ \\
\hline \multicolumn{6}{|l|}{ Entered as New Transfer } \\
\hline Career Center Total & $9.29^{* *}$ & $3,113.01$ & $<.001$ & .01 & $\begin{array}{l}1-4>0 * * * \\
5-9>0\end{array}$ \\
\hline Univ Center for Academic Excellence & $14.84^{* *}$ & $4,199.99$ & $<.001$ & .03 & $\begin{array}{l}0>1-4^{* * *} \\
0>5-10 \\
0>11-25\end{array}$ \\
\hline Writing Center & $5.17^{* *}$ & $2,112.17$ & $<.001$ & .004 & $\begin{array}{l}1>0 * * * \\
2+>0\end{array}$ \\
\hline High Impact Practices & $\begin{array}{l}29.83^{* *} \\
\text { **** }\end{array}$ & $2,47.72$ & $<.001$ & .01 & $\begin{array}{l}1-2>0 * * * \\
3-6>0 \\
3-6>1-2\end{array}$ \\
\hline Sports Club Membership & $4.49^{* *}$ & $1,34.12$ & .041 & .001 & $\mathrm{~N} / \mathrm{A}$ \\
\hline Library Book Checkouts & $5.17^{* *}$ & $2,317.14$ & .006 & .004 & $3+>0 * * *$ \\
\hline Library Study Room Reserv & $8.57^{* *}$ & $3,456.29$ & $<.001$ & .01 & $\begin{array}{l}16+>0 * * * \\
16+>1-5 \\
16^{+}>6-15\end{array}$ \\
\hline Library Instruction & 14.60 & $2,1944.00$ & $<.001$ & .02 & $\begin{array}{l}1>0 \\
2+>0\end{array}$ \\
\hline Library Computer Logins & $6.05^{* *}$ & $3,900.94$ & $<.001$ & .01 & $\begin{array}{l}0>1-10^{* * *} \\
0>11-30 \\
0>31+\end{array}$ \\
\hline Library EZ Proxy & 11.82 & $2,1944.00$ & $<.001$ & .01 & $\begin{array}{l}1-5>0 \\
6+>0\end{array}$ \\
\hline Library Laptop Checkouts & $4.23^{* *}$ & $2,201.97$ & .016 & .003 & $\begin{array}{l}2+>0^{* * *} \\
2+>1\end{array}$ \\
\hline Library After Hours Access & $3.86^{* *}$ & $2,67.26$ & .026 & .003 & $0>1^{* * *}$ \\
\hline
\end{tabular}

${ }^{*} \mathrm{p}<.05,{ }^{* *}$ Welch's ANOVA, ${ }^{* * *}$ Games-Howell Post Hoc Analysis, ${ }^{* * * *}$ Some groups $<30$ thus results may not be reliable. 
Table 2: Months to Graduation-Analysis of Variance-Significant Results

\begin{tabular}{|c|c|c|c|c|c|}
\hline Independent Variables & $F$ & $d f$ & Sig. $(p)$ & $\begin{array}{l}\text { Effect } \\
\left(\eta_{p}^{2}\right)\end{array}$ & $\begin{array}{l}\text { Post Hoc } \\
\text { Sig Results* }\end{array}$ \\
\hline \multicolumn{6}{|l|}{ Aggregate } \\
\hline Total Engagements Overall & $30.46^{* *}$ & $5,1122.34$ & $<.001$ & .04 & $\begin{array}{l}10-24>1-9 * * * \\
25-49>1-9 \\
50-74>1-9 \\
75-99>1-9 \\
100+>1-9 \\
75-99>10-24 \\
100+>10-24 \\
100+>25-49\end{array}$ \\
\hline Career Center Total & $19.67^{* *}$ & $3,343.51$ & $<.001$ & .02 & $\begin{array}{l}1-4>0 * * * \\
5-9>0 \\
10+>0\end{array}$ \\
\hline Univ Center for Acad Ex & $65.99 * *$ & $4,505.36$ & $<.001$ & .08 & $\begin{array}{l}1-4>0 * * * \\
5-10>0 \\
5-10>1-4 \\
11-25>0 \\
11-25>1-4 \\
26+>0\end{array}$ \\
\hline Sports Club Membership & $36.13^{* *}$ & $1,158.39$ & $<.001$ & 01 & $\mathrm{~N} / \mathrm{A}$ \\
\hline Greek Life Membership & $180.24^{* *}$ & $1,825.80$ & $<.001$ & .02 & $\mathrm{~N} / \mathrm{A}$ \\
\hline Library Total Engagements & $27.51^{* *}$ & $4,1499.92$ & $<.001$ & .03 & $\begin{array}{l}3-9>0-2^{* * *} \\
10-24>0-2 \\
25-74>0-2 \\
25-74>3-9 \\
75+>0-2 \\
75+>3-9 \\
75+>10-24\end{array}$ \\
\hline Library Study Room Reserv & $20.12^{* *}$ & $3,1318.00$ & $<.001$ & .02 & $\begin{array}{l}1-5>0 * * * \\
6-15>0 \\
16+>0 \\
16+>1-5\end{array}$ \\
\hline Library Book Checkouts & $66.15^{* *}$ & $2,939.66$ & $<.001$ & .031 & $\begin{array}{l}1-2>0 * * * \\
3+>0\end{array}$ \\
\hline Library Instruction & $56.08^{* *}$ & $2,2058.70$ & $<.001$ & .03 & $\begin{array}{l}1>0 * * * \\
2+>0 \\
2+>1\end{array}$ \\
\hline Library Computer Logins & 10.43 & 3, 1408.9 & $<.001$ & .01 & $\begin{array}{l}1-10>0 \\
11-30>0 \\
30+>0 \\
30+>1-10\end{array}$ \\
\hline Library EZ Proxy & $61.90^{* *}$ & $2,204.85$ & $<.001$ & .05 & $1-5>0 * * *$ \\
\hline
\end{tabular}




\begin{tabular}{|c|c|c|c|c|c|}
\hline Independent Variables & $F$ & $d f$ & Sig. $(p)$ & $\begin{array}{l}\text { Effect } \\
\left(\eta_{p}^{2}\right)\end{array}$ & $\begin{array}{l}\text { Post Hoc } \\
\text { Sig Results* }\end{array}$ \\
\hline & & & & & $6+>0$ \\
\hline Library Laptop Checkouts & $72.81^{* *}$ & $2,561.93$ & $<.001$ & .03 & $\begin{array}{l}1>0 * * * \\
2+>0 \\
2+>1\end{array}$ \\
\hline Library After Hours Access & $181.83^{* *}$ & $2,317.15$ & $<.001$ & .05 & $\begin{array}{l}1>0 * * * \\
2+>0 \\
2+>1\end{array}$ \\
\hline \multicolumn{6}{|l|}{ Entered as New Freshman } \\
\hline Total Engagements Overall & 9.43 & $5,2039.00$ & $<.001$ & .02 & $\begin{array}{l}10-24>1-9 \\
25-49>1-9 \\
50-74>1-9 \\
75-99>1-9 \\
100+>1-9 \\
75-99>10-24 \\
75-99>25-49 \\
100+>25-49 \\
100+>25-74\end{array}$ \\
\hline High Impact Practices & $33.26^{* *}$ & $2,131.11$ & $<.001$ & .01 & $\begin{array}{l}0>1-2^{* * * *} \\
0>3-6\end{array}$ \\
\hline Library Total Engagements & $11.32^{* *}$ & $4,744.22$ & $<.001$ & .02 & $\begin{array}{l}75+>0-2^{* * * *} \\
75+>3-9 \\
75+>10-24 \\
75+>25-74\end{array}$ \\
\hline Library Book Checkouts & 3.79 & $2,2042.00$ & .023 & .004 & $1-2>0$ \\
\hline Library Computer Logins & $10.64^{* *}$ & $3,720.93$ & $<.001$ & .02 & $\begin{array}{l}11-30>0^{* * *} \\
30+>0 \\
30+>1-10\end{array}$ \\
\hline Library EZ Proxy & $52.64^{* *}$ & $2,134.74$ & $<.001$ & .09 & $\begin{array}{l}1-5>0 * * * \\
6+>0\end{array}$ \\
\hline Library Laptop Checkouts & 8.45 & $2,462.43$ & $<.001$ & .01 & $\begin{array}{l}2+>0 \\
2+>1\end{array}$ \\
\hline Library After Hours Access & 36.28 & $2,2014.00$ & $<.001$ & .03 & $\begin{array}{l}2+>0 \\
2+>1\end{array}$ \\
\hline \multicolumn{6}{|l|}{ Entered as New Transfer } \\
\hline Total Engagements Overall & $7.90^{* *}$ & $5,295.35$ & $<.001$ & .03 & $\begin{array}{l}25-49>1-9^{* * *} \\
50-74>1-9 \\
75-99>1-9 \\
100+>1-9 \\
100+>10-24\end{array}$ \\
\hline
\end{tabular}




\begin{tabular}{|c|c|c|c|c|c|}
\hline Independent Variables & $F$ & $d f$ & Sig. $(p)$ & $\begin{array}{l}\text { Effect } \\
\left(\boldsymbol{n}_{p}^{2}\right)\end{array}$ & $\begin{array}{l}\text { Post Hoc } \\
\text { Sig Results* }\end{array}$ \\
\hline Career Center Total & 2.86 & $3,1422.00$ & .036 & .006 & $\begin{array}{l}10+>0 \\
10+>1-4\end{array}$ \\
\hline Univ Center for Academic Excellence & 22.20 & $4,1421.00$ & $<.001$ & .06 & $\begin{array}{l}1-4>0 \\
5-10>0 \\
11-25>0 \\
11-25>1-4 \\
11-25>5-10 \\
26+>0\end{array}$ \\
\hline Sports Club Membership & $4.23^{* *}, * * * *$ & $1,1424.00$ & .04 & .003 & $\mathrm{~N} / \mathrm{A}$ \\
\hline Greek Life Membership & 17.84 & $1,1424.00$ & $<.001$ & .01 & $\mathrm{~N} / \mathrm{A}$ \\
\hline Writing Center & 5.36 & $2,765.35$ & .005 & .000 & $1>0$ \\
\hline Library Total Engagements & $4.93^{* *}$ & $4,654.05$ & .001 & .01 & $\begin{array}{l}75^{+}>0-2^{* * *} \\
75^{+}>3-9 \\
75^{+}>10-24\end{array}$ \\
\hline Library Book Checkouts & 37.33 & $2,1423.00$ & $<.001$ & .05 & $\begin{array}{l}1-2>0 \\
3+>0\end{array}$ \\
\hline Library EZ Proxy & $11.25^{* *}$ & $2,62.37$ & $<.001$ & .03 & $\begin{array}{l}1-5>0 \text { *** } \\
6+>0\end{array}$ \\
\hline Library Laptop Checkouts & $41.82^{* *}$ & $2,167.43$ & $<.001$ & .05 & $\begin{array}{l}1>0 * * * \\
2+>0\end{array}$ \\
\hline Library After Hours Access & $65.79^{* *}$ & $2,52.67$ & $<.001$ & .05 & $\begin{array}{l}1>0 * * * \\
2+>0\end{array}$ \\
\hline
\end{tabular}

${ }^{*} \mathrm{p}<.05$

\section{**Welch's ANOVA}

***Games-Howell Post Hoc Analysis

**** One or more groups $<30$ thus results may not be reliable. 


\section{Appendix E}

Table 1: First Year GPA-Significant Regression Models*

\begin{tabular}{|c|c|c|c|}
\hline $\begin{array}{l}\text { Independent Variables } \\
(2012-2013)\end{array}$ & Aggregate $(B)$ & $\begin{array}{l}\text { Entered as } \\
\text { Freshman (B) }\end{array}$ & $\begin{array}{l}\text { Entered as } \\
\text { Transfers }(B)\end{array}$ \\
\hline \multicolumn{4}{|l|}{ Total of All Engagements } \\
\hline Constant & 2.939 & 2.975 & -- \\
\hline Total Engagements & $\begin{array}{l}.002 \\
R^{2}=.001 \\
\mathrm{~F}_{(1,4963)}=7.162 \\
p=.007\end{array}$ & $\begin{array}{l}.004 \\
R^{2}=.009 \\
\mathrm{~F}_{(1,2991)}=25.71 \\
p<.001\end{array}$ & $\begin{array}{l}-- \\
-- \\
-- \\
\text { Not significant }\end{array}$ \\
\hline \multicolumn{4}{|c|}{ Total Engagements x Partner } \\
\hline Constant & 2.931 & 2.961 & 2.846 \\
\hline Career Center & .063 & .088 & .041 \\
\hline Library & $\begin{array}{l}-- \\
R^{2}=.007 \\
\mathrm{~F}_{(1,4963)}=33.894 \\
p<.001\end{array}$ & $\begin{array}{l}.003 \\
R^{2}=.019 \\
\mathrm{~F}_{(2,2990)}=28.729 \\
p<.001\end{array}$ & $\begin{array}{l}-- \\
R^{2}=.003 \\
\mathrm{~F}_{(1,1945)}=6.342 \\
p<.012\end{array}$ \\
\hline \multicolumn{4}{|c|}{ Total Engagements x Activity } \\
\hline Constant & 2.898 & 2.944 & 2.841 \\
\hline Career Center & .094 & .144 & -- \\
\hline Fairs & .044 & .059 & .061 \\
\hline Advising & .054 & -- & .124 \\
\hline Library & -- & .003 & -- \\
\hline Instruction & .005 & -- & .007 \\
\hline Computer Logins & .019 & .024 & -- \\
\hline Study Room Reserv & $R^{2}=.018$ & $R^{2}=.034$ & $R^{2}=.009$ \\
\hline Univ Ctr for Acad. Excel. & $\mathrm{F}_{(5,4959)}=18.038$ & $\mathrm{~F}_{(4,2988)}=9.445$ & $\mathrm{~F}_{(3,1943)}=5.981$ \\
\hline Supplemental Instruc. & $p<.001$ & $p<.001$ & $p<.001$ \\
\hline \multicolumn{4}{|c|}{$\begin{array}{l}\text { Demographic Variables \& All } \\
\text { Partner Activities }\end{array}$} \\
\hline Constant & 1.003 & 1.035 & 1.297 \\
\hline HS GPA (Weighted) & .466 & .512 & .395 \\
\hline Non UNCC Credits & -- & -- & .004 \\
\hline
\end{tabular}




\begin{tabular}{|c|c|c|c|}
\hline $\begin{array}{l}\text { Independent Variables } \\
(2012-2013)\end{array}$ & Aggregate $(B)$ & $\begin{array}{l}\text { Entered as } \\
\text { Freshman }(B)\end{array}$ & $\begin{array}{l}\text { Entered as } \\
\text { Transfers }(B)\end{array}$ \\
\hline Gender (1=Male; $2=$ Female) & .137 & -- & -- \\
\hline Career Center Fairs & .098 & .123 & -- \\
\hline Advising & .047 & .051 & -- \\
\hline Library Computer Logins & .003 & .004 & -- \\
\hline $\begin{array}{l}\text { Univ Ctr for Acad. Excel. } \\
\text { Supplemental Instruc. }\end{array}$ & $\begin{array}{l}.013 \\
R^{2}=.183 \\
\mathrm{~F}_{(6,3412)}=127.225 \\
p<.001\end{array}$ & $\begin{array}{l}.015 \\
R^{2}=.175 \\
\mathrm{~F}_{(5,2801)}=118.676 \\
p<.001\end{array}$ & $\begin{array}{l}-- \\
R^{2}=.143 \\
\mathrm{~F}_{(2,594)}=49.411 \\
p<.001\end{array}$ \\
\hline \multicolumn{4}{|l|}{ Total Library Engagements } \\
\hline Constant & 2.943 & 2.986 & -- \\
\hline Total Library Engagements & $\begin{array}{l}.002 \\
R^{2}=.001 \\
\mathrm{~F}_{(1,4963)}=6.289 \\
p=.012\end{array}$ & $\begin{array}{l}.004 \\
R^{2}=.007 \\
\mathrm{~F}_{(1,2991)}=20.647 \\
p<.001\end{array}$ & $\begin{array}{l}-- \\
-- \\
-- \\
\text { Not significant }\end{array}$ \\
\hline \multicolumn{4}{|l|}{ Specific Library Activities } \\
\hline Constant & 2.937 & 2.988 & 2.846 \\
\hline Library Study Room Reserv & .006 & .004 & .007 \\
\hline Library Instruction & .050 & -- & .120 \\
\hline Library Computer Logins & $\begin{array}{l}-- \\
R^{2}=.004 \\
\mathrm{~F}_{(2,4926)}=9.396 \\
p<.001\end{array}$ & $\begin{array}{l}.004 \\
R^{2}=.007 \\
\mathrm{~F}_{(2,2990)}=10.44 \\
p<.001\end{array}$ & $\begin{array}{l}-- \\
R^{2}=.006 \\
\mathrm{~F}_{(2,1944)}=5.754 \\
p=.003\end{array}$ \\
\hline \multicolumn{4}{|l|}{$\begin{array}{l}\text { Demographic Variables \& } \\
\text { Specific Library Activities }\end{array}$} \\
\hline Constant & .994 & .862 & 1.297 \\
\hline HS GPA (Weighted) & .477 & .506 & .395 \\
\hline Non UNCC Credits & -- & .155 & .004 \\
\hline Gender (1=Male; $2=$ Female) & .139 & -- & -- \\
\hline Library Study Room Reserv & -- & .004 & -- \\
\hline
\end{tabular}




\begin{tabular}{|l|l|l|l|}
\hline $\begin{array}{l}\text { Independent Variables } \\
(2012-2013)\end{array}$ & Aggregate $(B)$ & $\begin{array}{l}\text { Entered as } \\
\text { Freshman }(B)\end{array}$ & $\begin{array}{l}\text { Entered as } \\
\text { Transfers }(B)\end{array}$ \\
\hline Library Computer Logins & .004 & .004 & - \\
& $R^{2}=.172$ & $R^{2}=.176$ & $R^{2}=.143$ \\
& $\mathrm{~F}_{(3,3415)}=237.223$ & $\mathrm{~F}_{(4,2802)}=149.488$ & $\mathrm{~F}_{(2,596)}=49.411$ \\
& $p<.001$ & $p<.001$ & $p<.001$ \\
\hline
\end{tabular}

${ }^{*}$ Significance level $p<.05$. Stepwise Regression used to determine which variables make a significant and positive contribution to improving GPA. Analyses were rerun using only positive factors.

Table 2: Cumulative GPA (Fall 2018)-Significant Regression Models*

\begin{tabular}{|c|c|c|c|}
\hline \multicolumn{4}{|l|}{ 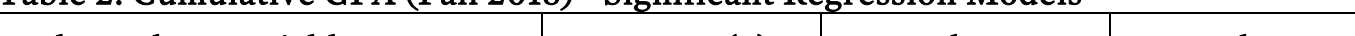 } \\
\hline Independent Variables & Aggregate $(B)$ & $\begin{array}{l}\text { Entered as } \\
\text { Freshman (B) }\end{array}$ & $\begin{array}{l}\text { Entered as } \\
\text { Transfers }(B)\end{array}$ \\
\hline \multicolumn{4}{|l|}{ Total of All Engagements } \\
\hline Constant & 2.878 & 2.879 & -- \\
\hline Total Engagements & $\begin{array}{l}.001 \\
R^{2}=.004 \\
\mathrm{~F}_{(1,4965)}=19.82 \\
p<.001\end{array}$ & $\begin{array}{l}.001 \\
R^{2}=.01 \\
\mathrm{~F}_{(1,2993)}=29.44 \\
p<.001\end{array}$ & $\begin{array}{l}-- \\
-- \\
-- \\
\text { Not significant }\end{array}$ \\
\hline \multicolumn{4}{|c|}{ Total Engagements x Partner } \\
\hline Constant & 2.826 & 2.830 & 2.820 \\
\hline Career Center & .033 & .035 & .027 \\
\hline Writing Center & .028 & .040 & .022 \\
\hline Total HIPs & $\begin{array}{l}.146 \\
R^{2}=.048 \\
\mathrm{~F}_{(3,4963)}=82.68 \\
p<.001\end{array}$ & $\begin{array}{l}.145 \\
R^{2}=.066 \\
\mathrm{~F}_{(3,2991)}=70.72 \\
p<.001\end{array}$ & $\begin{array}{l}.152 \\
R^{2}=.024 \\
\mathrm{~F}_{(3,1943)}=15.96 \\
p<.001\end{array}$ \\
\hline \multicolumn{4}{|c|}{ Total Engagements x Activity } \\
\hline Constant & 2.763 & 2.757 & 2.770 \\
\hline Career Center Fairs & .044 & .056 & .033 \\
\hline Workshops & .077 & .092 & .031 \\
\hline Advising & .015 & -- & -- \\
\hline Class Presentations & -- & -- & -- \\
\hline Library Instruction & .038 & .036 & .051 \\
\hline Book Checkouts & .006 & .007 & .004 \\
\hline EZ Proxy & .007 & -- & .013 \\
\hline Study Room Reservations & .002 & .002 & .002 \\
\hline
\end{tabular}




\begin{tabular}{|c|c|c|c|}
\hline Independent Variables & Aggregate $(B)$ & $\begin{array}{l}\text { Entered as } \\
\text { Freshman }(B)\end{array}$ & $\begin{array}{l}\text { Entered as } \\
\text { Transfers }(B)\end{array}$ \\
\hline $\begin{array}{l}\text { Univ Ctr for Acad. Excel. } \\
\text { Supplemental Instruc }\end{array}$ & .010 & .012 & -- \\
\hline Writing Center Consultations & .023 & .035 & -- \\
\hline Total HIPs & $\begin{array}{l}.137 \\
R^{2}=.071 \\
\mathrm{~F}_{(10,4956)}=38.08 \\
p<.001\end{array}$ & $\begin{array}{l}.139 \\
R^{2}=.096 \\
\mathrm{~F}_{(8,2986)}=39.83 \\
p<.001\end{array}$ & $\begin{array}{l}.145 \\
R^{2}=.043 \\
\mathrm{~F}_{(7,1939)}=12.43 \\
p<.001\end{array}$ \\
\hline \multicolumn{4}{|l|}{$\begin{array}{l}\text { Demographic Variables \& All } \\
\text { Partner Activities }\end{array}$} \\
\hline Constant & 1.474 & 1.545 & 1.333 \\
\hline HS GPA (Weighted) & .175 & .172 & .215 \\
\hline Non UNCC Credits & .002 & -- & -- \\
\hline Gender (1=Male; $2=$ Female) & -- & -- & -- \\
\hline SAT/ACT (Standardized) & .026 & .026 & .031 \\
\hline HIPs & .104 & .108 & -- \\
\hline Career Center Fairs & .038 & .041 & -- \\
\hline Workshops & -- & -- & -- \\
\hline Advising & .017 & .019 & .042 \\
\hline Class Presentations & .049 & -- & -- \\
\hline Library Instruction & .040 & .037 & -- \\
\hline Book Checkouts & .004 & .004 & -- \\
\hline Study Room Reservations & .002 & -- & -- \\
\hline $\begin{array}{l}\text { Univ Ctr for Acad. Excel. } \\
\text { Supplemental Instruc }\end{array}$ & .009 & .010 & -- \\
\hline Writing Center Consultations & $\begin{array}{l}.054 \\
R^{2}=.191 \\
\mathrm{~F}_{(12,2956)}=58.143 \\
p<.001\end{array}$ & $\begin{array}{l}.056 \\
R^{2}=.183 \\
\mathrm{~F}_{(9,2959)}=73.842 \\
p<.001\end{array}$ & $\begin{array}{l}-- \\
R^{2}=.140 \\
\mathrm{~F}_{(3,2512)}=137.966 \\
p<.001\end{array}$ \\
\hline \multicolumn{4}{|l|}{ Total Library Engagements } \\
\hline Constant & 2.844 & 2.891 & -- \\
\hline Total Library Engagements & $\begin{array}{l}.001 \\
R^{2}=.003 \\
\mathrm{~F}_{(1,4965)}=15.2 \\
p<.001\end{array}$ & $\begin{array}{l}.001 \\
R^{2}=.007 \\
\mathrm{~F}_{(1,2993)}=21.2 \\
p<.001\end{array}$ & $\begin{array}{l}-- \\
-- \\
-- \\
\text { Not significant } \\
\end{array}$ \\
\hline Specific Library Activities & & & \\
\hline
\end{tabular}




\begin{tabular}{|c|c|c|c|}
\hline Independent Variables & Aggregate $(B)$ & $\begin{array}{l}\text { Entered as } \\
\text { Freshman }(B)\end{array}$ & $\begin{array}{l}\text { Entered as } \\
\text { Transfers }(B)\end{array}$ \\
\hline Constant & 2.836 & 2.847 & 2.821 \\
\hline Library Instruction & .042 & .038 & .048 \\
\hline Library Book Checkouts & .006 & .008 & .004 \\
\hline Library Study Room Reserv & .003 & .003 & .003 \\
\hline Library EZ Proxy & $\begin{array}{l}.008 \\
R^{2}=.026 \\
\mathrm{~F}_{(4,4962)}=36.61 \\
p<.001\end{array}$ & $\begin{array}{l}-- \\
R^{2}=.028 \\
\mathrm{~F}_{(3,2991)}=29.15 \\
p<.001\end{array}$ & $\begin{array}{l}.012 \\
R^{2}=.022 \\
\mathrm{~F}_{(4,1942)}=11.13 \\
p<.001\end{array}$ \\
\hline \multicolumn{4}{|l|}{$\begin{array}{l}\text { Demographic Variables \& } \\
\text { Specific Library Activities }\end{array}$} \\
\hline Constant & .761 & .482 & 1.161 \\
\hline Weighted HS GPA & .399 & .445 & .312 \\
\hline SAT/ACT (Standardized) & .019 & .023 & .021 \\
\hline Non-UNCC Credits & .002 & -- & .004 \\
\hline Internships & .128 & .142 & -- \\
\hline Library Book Checkouts & .005 & .006 & -- \\
\hline Library Instruction & .041 & .047 & -- \\
\hline Library Study Room Reserv & .003 & .003 & -- \\
\hline Library EZ Proxy & $\begin{array}{l}.005 \\
R^{2}=.186 \\
\mathrm{~F}_{(8,2960)}=84.333 \\
p<.001\end{array}$ & $\begin{array}{l}-- \\
R^{2}=.195 \\
\mathrm{~F}_{(6,2509)}=101.098 \\
p<.001\end{array}$ & $\begin{array}{l}-- \\
R^{2}=.163 \\
\mathrm{~F}_{(4,434)}=28.234 \\
p<.001\end{array}$ \\
\hline
\end{tabular}

*Significance level $p<.05$. Stepwise Regression used to determine which variables make a significant and positive contribution to improving GPA. Analyses were rerun using only positive factors. 
Table 3: Months to Graduation-Significant Regression Models*

\begin{tabular}{|c|c|c|c|}
\hline Independent Variables & Aggregate (B) & $\begin{array}{l}\text { Entered as } \\
\text { Freshman (B) }\end{array}$ & $\begin{array}{l}\text { Entered as } \\
\text { Transfers }(B)\end{array}$ \\
\hline \multicolumn{4}{|l|}{ Total Engagements x Partner } \\
\hline Constant & 65.652 & 51.208 & 62.206 \\
\hline Greek Membership & -5.424 & -- & -7.768 \\
\hline Sports Team or Club & -5.129 & -- & -4.806 \\
\hline Total HIPs & $\begin{array}{l}-- \\
R^{2}=.03 \\
\mathrm{~F}_{(2,2487)}=53.83 \\
p<.001\end{array}$ & $\begin{array}{l}-.925 \\
R^{2}=.013 \\
\mathrm{~F}_{(1,2043)}=25.85 \\
p<.001\end{array}$ & $\begin{array}{l}-- \\
R^{2}=.015 \\
\mathrm{~F}_{(2,1423)}=11.02 \\
p<.001\end{array}$ \\
\hline \multicolumn{4}{|l|}{ Total Engagements x Activity } \\
\hline Constant & 65.652 & 51.208 & 52.731 \\
\hline Sports Team or Club & -5.129 & -- & -- \\
\hline Greek Organization & -5.424 & -- & -7.793 \\
\hline Total HIPs & $\begin{array}{l}-- \\
R^{2}=.03 \\
\mathrm{~F}_{(2,3487)}=53.83 \\
p<.001\end{array}$ & $\begin{array}{l}-.925 \\
R^{2}=.013 \\
\mathrm{~F}_{(1,2043)}=25.85 \\
p<.001\end{array}$ & $\begin{array}{l}-- \\
R^{2}=.012 \\
\mathrm{~F}_{(1,1424)}=17.84 \\
p<.001\end{array}$ \\
\hline \multicolumn{4}{|l|}{$\begin{array}{l}\text { Demographic Variables \& All } \\
\text { Specific Partner Activities }\end{array}$} \\
\hline Constant & 58.362 & 60.550 & 51.205 \\
\hline Non-UNCC Credits & -.267 & -.146 & -.259 \\
\hline Gender (1=Male; $2=$ Female) & -1.837 & -1.965 & -- \\
\hline Total HIPs & -.685 & -.815 & -- \\
\hline Sports Clubs/Teams & -1.645 & -- & -- \\
\hline Weighted HS GPA & $\begin{array}{l}-- \\
R^{2}=.42 \\
\mathrm{~F}_{(4,3485)}=626.28 \\
p<.001\end{array}$ & $\begin{array}{l}-1.426 \\
R^{2}=.107 \\
\mathrm{~F}_{(4,1910)}=57.33 \\
p<.001\end{array}$ & $\begin{array}{l}-- \\
R^{2}=.183 \\
\mathrm{~F}_{(1,1424)}=318.36 \\
p<.001\end{array}$ \\
\hline \multicolumn{4}{|l|}{$\begin{array}{l}\text { Demographic Variables \& } \\
\text { Specific Library Activities }\end{array}$} \\
\hline Constant & 62.088 & 62.045 & 75.900 \\
\hline Non-UNCC Credits & -2.877 & -1.399 & -4.984 \\
\hline Gender (1=Male; $2=$ Female) & -2.156 & -1.937 & -2.246 \\
\hline Total HIPs & -.708 & -.770 & -- \\
\hline Sports Clubs/Teams & -1.487 & -- & -- \\
\hline
\end{tabular}




\begin{tabular}{|c|c|c|c|}
\hline Independent Variables & Aggregate $(B)$ & $\begin{array}{l}\text { Entered as } \\
\text { Freshman (B) }\end{array}$ & $\begin{array}{l}\text { Entered as } \\
\text { Transfers }(B)\end{array}$ \\
\hline Weighted HS GPA & -- & -1.422 & -- \\
\hline Greek Organization & $\begin{array}{l}-- \\
R^{2}=.242 \\
\mathrm{~F}_{(4,2349)}=187.3 \\
p<.001\end{array}$ & $\begin{array}{l}-- \\
R^{2}=.091 \\
\mathrm{~F}_{(4,1910)}=47.6 \\
p<.001\end{array}$ & $\begin{array}{l}-4.775 \\
R^{2}=.231 \\
\mathrm{~F}_{(3,425)}=42.5 \\
p<.001\end{array}$ \\
\hline
\end{tabular}

*Significance level $p<.05$. Stepwise Regression used for initial analysis to determine variables that make a significant contribution to reducing Months-to-Graduation. Analyses were rerun using these factors. 